\title{
PETE SEEGER: A SINGER OF FOLK SONGS
}

\author{
DAVID LIVINGSTONE \\ Palacký University
}

\begin{abstract}
Pete Seeger would have turned one hundred and one on May 3 of this year. To commemorate these ten decades plus one year, I would like to look at eleven of the most remarkable aspects of Pete Seeger's life, work and legacy. This paper will examine the cultural impact and oral tradition of the music, songs and books of Pete Seeger. This legendary folk musician's career spanned eight decades and touched on many of the key historical developments of the day. He is responsible for some of the iconic songs which have not only helped define American culture, but even beyond. Seeger was also a pioneer in a number of fields, using his music to propagate political convictions, ecological themes, civil rights, world music, education, etc. The folk singer also had his finger on the pulse of a number of developments in American history and culture. He was friends with a number of prominent musicians and artists and influenced an entire range of younger musicians and activists.
\end{abstract}

Keywords: Pete Seeger; Folk music; American history; Social activism; Civil Rights movement

\section{Family}

Pete Seeger' family was a powerhouse of talent, musically and beyond. Charles Seeger (1886-1979), his father, was a renowned musicologist who held a number of prominent university positions. His political convictions, obviously on the left, were also instrumental in forming his son's ideological worldview. His mother Constance de Clyver (1886-1975) was also a musician although not as accomplished by far as his stepmother Ruth Seeger (1901-1953) (mother to Mike and Peggy). Charles' younger brother Alan Seeger (1888-1916) was a poet, who died in World War I, most famous for his classic poem "I Have a Rendezvous with Death.”

Mike Seeger (1933-2009) was the most musically gifted of the siblings (at least according to Pete), playing the banjo, guitar, violin, autoharp and a 
range of additional folk instruments. His band The New Lost City Ramblers, which came to prominence in the late 1950s, was a key group in the Folk Revival. Peggy Seeger (1935) is very much alive and still performing and writing. She recently published a remarkable autobiographical book First Time Every: A Memoir. She has written and popularized thousands of songs, but is arguably most well-known for her feminist anthem Gonna Be an Engineer. Her marriage to the British folk singer Ewan MacColl is recalled, amongst other things, by his song The First Time Ever I Saw Your Face, written by him for her and made into a major hit by Roberta Flack.

Pete Seeger’s wife Toshi (1922-2013) has not always received the credit she deserves, having been, amongst other things, the director (although referred to as 'Chief Cook and Bottle Washer' in the credits) of Pete's amazing television show from the 1960s Rainbow Quest. She also made a number of other films, connected with both her husband and a range of other topics and was deeply involved in their environmental efforts. Tao Rodríguez-Seeger, their grandson, is a folksinger in his own right continuing to further the family legacy. His performance alongside his grandfather and Bruce Springsteen of Woody Guthrie's This Land is Your Land at President Obama's inauguration in 2009 is a must-see. Links to the performances mentioned in this text are included in the bibliography.

\section{Colleagues and friends}

Pete Seeger was influenced by and impacted in turn a number of major cultural figures of the twentieth century. His early cooperation with John and Alan Lomax (arguably the most important ethnomusicologists ever) had a profound impact as he became a tireless propagator of songs, not only from the United States and the British Isles but from all over the world. His interest in the banjo in particular was primarily due to the influence of the renowned folk musicians Bascom Lamar Lunsford and Uncle Dave Macon.

Seeger was friends and colleagues with a range of folk/country musicians: Woody Guthrie, Leadbelly, Josh White, Burl Ives, to name just a few of his early collaborators. A number of these figures were part of his first band The Almanac Singers, while his band The Weavers finally achieved chart success in the 1950s. Guthrie, in particular, was instrumental in his formation as the Oklahoman introduced the squeaky-clean Seeger to life on the wrong side of the tracks, taking him along on a hitchhiking tour of America and teaching him how to busk on the street. Guthrie's career was tragically shortened by Huntington's disease, his family curse. His friend, however, continued to play and celebrate his songs, becoming the most dedicated interpreter of his work. Seeger was also inspired to inscribe the words "This Machine Surrounds Hate and Forces It To Surrender” on his banjo, a gentler, more pacifist variation of 
Guthrie’s fiery, fighting words “This Machine Kills Fascists” written on his battered guitar.

Seeger consequently championed and supported several more generations of folk, country and rock musicians including Bob Dylan, the Kingston Trio, Peter Paul and Mary, Tom Paxton, Malvina Reynolds, Woody's son Arlo, Bruce Springsteen, Billy Bragg and many, many others. He helped establish the most famous folk festival in the world in 1959 The Newport Folk Festival, which still exists up until the present. The Seeger family was also instrumental in discovering the African-American guitarist and folk singer Elizabeth Cotton, most famous for her song Freight Train.

\section{Performances and concerts}

Pete Seeger recorded around one hundred albums despite the fact that this was not his primary musical interest. He was much more interested in playing live, whether that be for a crowd of thousands at a festival or for a small classroom of children. His concerts were always a shared experience, involving getting his audience to sing along with him. Seeger had very little need to show off his considerable musical skills, but was instead passionately dedicated to including the audience in the show, something along the lines of a church service.

Each of the concerts was unique, with a different audience, with Seeger often responding to the feel of the crowd. The sing-along style helped the audience become children once again, losing that awkward worry about the sound of one's voice. Seeger described it in his own words as follows: "They are not concerts so much as singalongs. My main purpose is to show people how good it is to sing together, and my main purpose on this record is to show future songleaders some of the techniques they can use in teaching songs without everyone's nose being buried in a sheet of paper” (Seeger 41).

Seeger would also frequently feed his audience members the lines of the songs as he played. He was able to get almost any kind of audience to get involved and would willingly perform for anyone who asked. He had this remarkable ability to help people lose self-consciousness, stemming from his own complete lack of vanity or affectation. His concert approach and his concept of a song leader can be seen clearly in a clip of him performing one of his classic songs If I Had a Hammer as well as in numerous other ones. Gene Marine in his article "Guerrilla Minstrel” included in the Pete Seeger Reader describes Seeger's distinct approach accurately: “And today, when we respond to Pete Seeger's presence on a stage, it is, I think, for a similar

reason: we know that he is singing what he thinks, what he feels, what he is right then and there-and we feel the liberating impulse to respond to openness with openness, to unshakeable honesty with whatever honesty we can command in return” (Cohen 34). 
Along with Woody Guthrie, Seeger was really the person who defined the notion of a folk singer or singer-songwriter as we view him or her today. Prior to these two, country music was more or less apolitical in its approach and philosophy. Seeger was also instrumental in establishing the notion of a socalled 'hootenanny', an informal jam session of folk musicians, back in the early 1940s with the Almanac Singers. This musical gathering is, of course, a direct precursor to the contemporary open mic, where so many folk singers and performers have received their first opportunity to perform. Seeger also famously defined classical music as music performed by others and folk music as music played by people themselves. This has done a great deal, in my mind, to empowering 'ordinary' people to pick up instruments and 'play' as opposed to 'perform' music.

\section{Songs}

Pete Seeger repeatedly referred to himself as a singer of folk songs as opposed to a folk singer. His approach to songs and music was distinct to say the least. His repertoire consisted of thousands of songs, from traditional ballads, to his own songs, to those by his contemporaries. He would use these songs to teach history, discuss politics, organize various events, especially union events and ecological issues, educate and entertain children, etc. Concerning his approach to songs, Seeger quoted his own father, calling it the folk process, "Our songs are, like you and me, the product of a long, long human chain, and even the strangest ones are distantly related to each other, as are we all. Each of us can be proud to be a link in this chain. Let's hope there are many more links to come. No: Let's make damn sure there are more links to come” (Seeger 43).

His most famous songs are often a product of a long chain. His song Turn, Turn, Turn made into a hit by the Byrds in 1965 came from the book of Ecclesiastes in the Bible. Seeger took very little credit for his arguably most well-known and influential song We Shall Overcome, only supposedly changing the world 'will' to 'shall'. He, in his own account, took part of the lyrics for Where Have All the Flowers Gone from a Cossack song quoted in the Russian novel And Quiet Flows the Don, which he put to the melody of a traditional Irish folk song. Additional hits of his were written by contemporaries such as Tom Paxton (What Did You Learn In School Today), Malvina Reynolds (Little Boxes) and of course Guthrie's songs, most famously This Land Is Your Land. Bruce Springsteen released an album of Seeger 'covers' We Shall Overcome: The Seeger Sessions, to much critical and popular acclaim in 2006, none of which, except for the title track, were actually written by the older musician. This did not bother Seeger a bit, who was extremely pleased about the album, not because of the attention drawn to him, but due to another generation growing an acquaintance with the songs and with the folk process. 


\section{Politics}

Seegers' politics have often overshadowed much of his work. Seeger, along with most of his fellow musicians from the early days, was a leftist. He joined the Communist Party USA in 1941 only to leave it in 1949. Throughout his career, Seeger has been an untiring supporter of a range of left-wing causes, particularly union labour movements. In 1955, at the time of the Red Scare and McCarthyism, he was even called in front of the House Un-American Activities Committee, where he famously defended his actions with the following words: "I am not going to answer any questions as to my association, my philosophical or religious beliefs or my political beliefs, or how I voted in any election, or any of these private affairs. I think these are very improper questions for any American to be asked, especially under such compulsion as this." (Dunaway, xiii). He asked the committee if he would be allowed to play and song one of his songs for them, but was denied. Although found guilty by the committee, he never had to serve prison time. He was, however, blacklisted for a number of years and had great difficulty finding work either performing or recording. Seeger toured the Soviet Union along with a number of other Communist countries in 1964 and later admitted to a definite naivety in his view of them. From being vilified in the 1950s, Seeger came full-circle when awarded the Presidential Medal of the Arts in 1994.

\section{Protester, Organizer and Educator}

Seeger kept busy during the blacklist years by basically taking whatever he could get. He performed at countless union events and a range of schools from primary to university level. His union involvement dated back even earlier, of course, and continued up until his final days. The union songs from his days with the Almanac Singers were mostly written by Woody Guthrie, including the classic Union Maid, but became a permanent part of Seeger's repertoire. His sympathy for working-class movements was not by any means limited to his native country as evidenced by his popularization of The Bells of Rhymney by the Welsh poet Idris Davies, chronicling the plight of Welsh coal miners:

Oh, what will you give me?

Say the sad bells of Rhymney.

Is there hope for the future?

Cry the brown bells of Merthyr.

Who made the mine owner?

Say the black bells of Rhondda.

And who robbed the miner?

Cry the grim bells of Blaina. 
Seeger released a number of albums for children and was always ready and willing to perform for a pittance for school kids. Perhaps his most permanent contribution to education was his performance of Tom Paxton's song What Did You Learn in School Today, the lines of which are still painfully relevant today.
What did you learn in school today
Dear little boy of mine?
I learned our country must be strong
It's always right and never wrong
Our leaders are the finest men
And we elect them again and again

He returned to the public eye in the early 1960s with his involvement and support for the Civil Rights movement. His songs, like We Shall Overcome and We Shall Not Be Moved became important anthems of the time, often sung by African Americans and their sympathizers during protests, sit-ins and gettogethers. Martin Luther King Jr. immediately took a liking to the firstmentioned song and quoted from it a number of times during his sermons; the song was finally sung at his funeral by thousands of distraught, but still undaunted, mourners. Incidentally, the Almanac Singers back in the 1940s were ground-breaking in being racially mixed at times, with their inclusion of Leadbelly, Josh White and others. Seeger's remarkable television program, Rainbow Quest, which aired from 1965 to 1966 also had an multi-cultural, interracial cast of musicians including African Americans, Latinos, British, Irish, Cajuns, Native Americans and others.

Pete Seeger was once again full front and centre during the Occupy Wall Street movement in 2011, tirelessly singing songs and encouraging both young and old to action.

\section{World Music}

Seeger was a champion of World Music before the term even existed. He travelled all over the world performing and learning about the folk customs of various countries and traditions. He was often disappointed to see foreign musicians playing American songs instead of exploring their own rich, and often neglected, traditions. He used his own platform to popularize and adapt a number of foreign songs he came across on his travels. One of the most famous of these is Wimoweh or The Lion Sleeps Tonight a South African Zulu song which Alan Lomax introduced to Seeger and which consequently became a hit for The Weavers. The camp-fire standards Michael Row the Boat Ashore and Kumbaya both of Gullah origin, African American creole culture, were helped popularized by Seeger. 
He has also been instrumental in encouraging the revival of interest in folk music in the British Isles and many other countries, including the Czech Republic, the tradition of which the present author is most familiar with. Seeger also helped propagate the calypso music tradition of the Caribbean with the publication of a manual on how to play the steel drum and a consequent followup film directed by his wife. He recorded and sang a number of songs in Spanish, Hebrew and many other languages. He would almost always try to learn a song in the language of the country he was visiting. Many of his greatest hits have also become extremely influential in translation, the most famous example of which is Marlene Dietrich's German version of Where Have All the Flowers Gone from 1962. Returning to my own adopted country, the Czech version of We Shall Overcome was sung famously on Wenceslas Square to kick off the Velvet Revolution of 1989.

\section{Ecological Activism}

A less known aspect of Seeger's activism is his untiring support for ecological issues and causes. Pete and Toshi bought land and built a house in Beacon, New York where they lived until their respective deaths. The town is on the Hudson River and the Seegers founded a campaign, the Hudson River Sloop Clearwater, in 1966, which included a boat and a music festival all focused on environmental activism, specifically cleaning up the river. He released an environmental album in 1982 God Bless the Grass which included the eponymous song written once again by Malvina Reynolds along with his own tune My Dirty Stream about his beloved Hudson River.

Sailing down my dirty stream

Still I love it and I'll keep the dream

That some day, though maybe not this year

My Hudson River will once again run clear

The program Pete Seeger at Home, available on-line, shows him in his element, chopping wood and walking the land around the house he and his wife built with their own hands.

\section{Publications and Programs}

Mention has already been made of the husband and wife television program The Rainbow Quest. Most of the episodes are now on youtube and are remarkable, not only for the star-studded performers, but for its modest, folksy, approach. Highlights include a remarkable performance of "My Country 'Tis of Thy People You're Dying," by the First Nations singer Buffy Sainte-Marie, a visit by 
Mississippi John Hurt, Johnny and June Cash and many others. Seeger was also able to bridge the quickly spreading gap between country music, often on the right politically from the 1950s on, and the left-wing folk movement. Apart from the Cashes, he had country icons such as Doc. Watson, The Stanley Brothers, Jean Ritchie and Roscoe Holcomb on the show. My personal favourite segment is when the country legend Cousin Emmy performs You Are My Sunshine on a plastic glove in high heels while Seeger accompanies her with a big smile.

Seeger was also a prolific writer of a range of publications throughout his lifetime. These ranged from manuals (the already mentioned steel drum book, most famously his how to play the banjo manual from 1948 which inspired several more generations of musicians), to articles in folk magazines such as Sing Out a quarterly folk journal which he co-founded and which was published for 64 years, Broadside magazine and others. His writings have been collected in the indispensable Pete Seeger Reader. There are also a number of remarkable interviews available online, on youtube and elsewhere.

\section{Authenticity}

One of my favourite stories about Seeger is when he was involved in a festival the profits of which were supposed to go to a certain cause. He suggested all those involved, who were already playing for free, should bring their own box lunch with them in order to maximize the monies for the non-profit. A number of mainstream acts were on the bill and were understandably taken aback by this odd request, but could not say no, considering who the suggestion had come from. Marine attempts to define Seeger's unique character and attitude to his audience as follows: “... his amazing rapport with audiences is somehow closely connected to his personal integrity. And that, in turn, is hard to write about" (Cohen 17). Seeger seems to have had a complete lack of guile, and a rare ability to be fully sincere without losing his sense of humour.

\section{Unwavering Optimism}

One could, of course, continue with a discussion of topics which Seeger embodied and celebrated in his life and work. Seeger was an outspoken feminist, he was an early advocate for LGBT rights, the list goes on and on. His undying optimism, however, will be our final discussion point. His undying enthusiasm, almost unprecedented in its intensity, can be seen in the earlier-mentioned inauguration performance. Wearing a ski cap at a jaunty angle, he performs the song, which he has obviously played thousands of times over the years, with a manic pleasure. At the end of the performance, he runs off the stage, to the obvious surprise of Springsteen, not a man known for being slow on his feet. 
In an interview for Democracy Now in 2004, at the age of 85, Seeger summarized his never-say-die spirit both poetically and poignantly.

\begin{abstract}
I honestly believe that the future is gonna be millions of little things saving us. I imagine a big see-saw and one end of the see-saw is on the ground with a basket half-full of big rocks, the other end of the see-saw is up in the air and it's gotta a basket one quarter full of sand. And some of us have got t-spoons and we're trying to fill up sand. A lot of people are laughing at us, they say ah people like you have been trying to do that for thousands of years and it's leaking out as fast as you're putting it in. But we're saying, we're getting more people with t-spoons all the time and we think one of these years, you'll see that whole see-saw go shoozup (makes a downward motion with his arm) in the other direction and people say gee, how did it happen so suddenly. Us and all our little t-spoons. And we've got to keep putting it in, because if we don't keep putting t-spoons in, it will leak out and the rocks will go back again. (Pete Seeger Interview)
\end{abstract}

Seeger would begin practically every performance, be it at a huge rock festival or in front of a class of schoolchildren by playing and singing a traditional folk song, John Henry. The song exists in many versions and with many variations, but usually consists of a celebration of an African-American railroad worker, who challenges a newly introduced drilling-machine to a competition. He is victorious in the end, but "dies with a hammer in my hand", seemingly of a heart-attack. This song is near and dear to Seeger's heart for a number of reasons, as it celebrates the working man, focuses on the dignity of a minority and critiques the way technology is dehumanizing humanity. It is also an apt metaphor for Seeger's own love affair with his distinct long-necked banjo. John Henry is also easy to sing and therefore ideally suited for Seeger's distinct approach to performance, where he is more interested in the audience singing along with him then highlighting his own voice and musical skill. The song most-importantly, however, holds out hope for the underdog even when everything seems completely lost. We are in need of this fervent optimism now more than ever.

\title{
References
}

Dubois, Laurent. The Banjo: America's African Instrument. Cambridge: The Belknap Press of Harvard University Press, 2016. Print.

Dunaway, David King. A Pete Seeger Discography. Lanham: The Scarecrow Press, Inc., 2011. Print.

Lomax, Alan. The Penguin Book of American Folk Songs. Middlesex: Penguin Books Ltd., 1964. Print. 
Lomax, John. A \& Alan Lomax. American Ballads and Folk Songs. New York: The Macmillan Company, 1934. Print.

Marine, Gene. “Guerrilla Minstrel.” The Pete Seeger Reader. Ed. Cohen, Ronald P. \& James Capaldi. New York: Oxford University Press, 2014. 40-48. Print.

Seeger Pete. The Smithsonian Folkways Collection. Washington, D.C.: Smithsonian Institution, 2019. Print.

Shaw, John This Land That I Love. New York: Public Affairs, 2013. Print.

\section{Electronic Sources}

"1960s Pete Seeger Performs 'If I Had a Hammer'." YouTube, 15 April 2020, $<$ https://www.youtube.com/watch?v=GVyVqnlFTdA $>$.

"Cousin Emmy, Rainbow Quest (1965)." YouTube, 15 April 2020, $<$ https://www.youtube.com/watch?v=dL14kOgO0-U>.

"Gonna Be An Engineer (1979)." YouTube 15 April 2020, $<$ https://www.youtube.com/watch?v=8IGVxBb5uYk>.

"John Henry - Pete Seeger." YouTube 15 April 2020, < https://www.youtube.com/watch?v=A9Zt0O2lyhk>.

"My Dirty Stream (1966)." YouTube 15 April 2020, $<$ https://www.youtube.com/watch?v=NfxgGx2xkw8>.

"Pete Seeger at Home (1989)." YouTube, 15 April 2020, $<$ https://www.youtube.com/watch?v=jgZekxKZwik>.

"Pete Seeger Interview on Democracy Now in '04 (2004)." $<$ https://www.youtube.com/watch?v=0gIhFYPqIxA $>$.

"Pete Seeger - The Bells Of Rhymney (1964). YouTube 15 April 2020, $<$ https://www.youtube.com/watch?v=vK_eVaLeiQ0>.

"Pete Seeger - This Land is Your Land (2009)." YouTube 15 April 2020, $<$ https://www.youtube.com/watch?v=HE4H0k8TDgw>.

"Pete Seeger - What Did You Learn In School? (1964)." YouTube 15 April 2020, $<$ https://www.youtube.com/watch?v=VucczIg98Gw>.

"Rainbow Quest: Buffy Sainte-Marie - My Country Tis of Thy People You're Dying (1966)." YouTube 15 April 2020, <https://www.youtube.com/watch?v=FKKXH3NMNI>.

\section{BIONOTE}

David Livingstone is an American living and working for almost 30 years in the Czech Republic. He teaches English Literature, with a specialization in Shakespeare, at Palacký University in Olomouc. He also has classes in American Folk Music, Children's Literature and Czech Culture. His hobbies include beer, the banjo and travelling. His latest publication is called In our Own Image: Fictional Representations of William Shakespeare.

E-mail: Livingstone@seznam.cz 